\title{
Prevalence of Ectoparasitic Arthropods on Free Range Domestic Fowls (G. domesticus) in Amansea and Ifite Communities (Awka, Nigeria)
}

\author{
Nwadike Comfort Chidiogo ${ }^{1, *}$, Ilozumba Philip C. O ${ }^{2}$, Chukwudi Gaius James ${ }^{2}$ \\ ${ }^{1}$ Department of Integrated Science, Nwafor Orizu College of Education Nsugbe, Nigeria \\ ${ }^{2}$ Department of Zoology, Nnamdi Azikiwe University Awka, Nigeria
}

Received November 22, 2019; Revised December 14, 2019; Accepted December 25, 2019

Copyright $\odot 2020$ by authors, all rights reserved. Authors agree that this article remains permanently open access under the terms of the Creative Commons Attribution License 4.0 International License

\begin{abstract}
A survey was carried out to determine the prevalence of ectoparasitic arthropods in free range domestic fowl (Gallus domesticus) in Amansea and Ifite communities. A total of $112 \mathrm{G}$. domesticus comprising of 42 adult males, 30 adult females and 40 juveniles with plumage of different colours were examined during a house to house survey for ectoparasitic arthropods. The study was carried out between June and September, 2014. Out of the 12 G. domesticus having white plumage, $(58.33 \%)$ were infested with lice. Fleas were absent on white plumage birds. The $19 \mathrm{G}$. domesticus having black plumage, $(47.37 \%)$ were infested by lice. Fleas were also absent on black plumage birds. Out of 34 brown coloured $G$. Domesticus examined, lice, fleas and mites were recorded to have the same number of infestation $(17.65 \%)$ each, while $(29.41 \%)$ were infested by ticks. Out of $47 G$. domesticus having mixed colour plumage, $(40.42 \%)$ were infested by lice. Chi-squared test showed that there was no significant difference between ectoparasites loads on the host and the different plumage colours $(\mathrm{P}>0.05)$. Because of the high prevalence of ectoparasitic arthropods revealed in this study, it is recommended that some control measures should be put in place to improve chicken productivity and enhance the livelihood of these domestic fowls in the areas investigated.
\end{abstract}

Keywords Gallusdomesticus, Ectoparasites, Prevalence, Plumage, Occurrence, Arthropods, Free-range

\section{Introduction}

Chicken can be managed using two systems namely, open (free - range) and restricted (confined system). In free -range system, chickens move about freely over a wide area in search of food. They are always hardy, breeding is natural, which in turn saves hatchery costs and other expenses and their strong nature may partially be expressed in disease resistance [1].

In the rural system of management of poultry, the birds are left to scavenge around the house during the day time to obtain what feed they may be able to get from the environment often as offal, insects and seeds. Owing to the free range and scavenging attitude, traditional village birds are in permanent contact with soil and insects. Soil when humid and warm may serve as an important reservoir transmission site for external larval stages of parasites [2].

Parasitism ranks high among factors that threaten free range chicken production [3]. Arthropod ectoparasites have a major impact on husbandry, productivity and welfare of domestic animals [4]. Due to their numerous activities, ectoparasitic arthropods have two types of effects on their host, which are direct and indirect effects. Direct damages caused according to [5], are blood loss, myiasis, skin inflammation, pruritis and toxic and allergic responses caused by antigens and anticoagulants in the saliva of blood feeding arthropods. Ectoparasitic arthropods such as ticks, suck blood and interfere with the feed consumption by giving continuous irritation. Thus, they are associated with emaciation, anaemia and eventually loss of production. In some cases, severely affected birds may die [6]. The major effects of these parasites on their host are due to the irritation they cause. Ectoparasites found on poultry birds belong to phylum Arthropoda, and of two classes: Arachnida, having the orders Acarina (ticks and mites) and the Insectawhich includes orders Phthiraptera (lice), and Siphonaprera (fleas) [7]. Ectoparasitic arthropods carnage feathers, irritate and cause skin lesions, resulting in reduced performance of adult chicken and direct harm to young chicks [8] [9].

Feeding activity of the ectoparasites may result in 
significant blood loss, secondary infestations, pruritus, and excoriation and in some cases premature death. Ectoparasites may also cause indirect harm including behavioural disturbances, such as increased frequency of rubbing or scratching, leading to reduced time in feeding [10] [11] [12]. In addition, ectoparasitic infestation as related to the fur conditions and the colour shades of the chickens are lacking. The purpose of this study was to identify ectoparasites found on domestic chickens by plumage in Amansea and Ifite communities in Awka, Anambra state and to ascertain the distribution of the parasites on the body of the chicken. It is hoped that the results could be used in making objective decisions in control strategies.

\section{Materials and Methods}

\subsection{Area of Study}

This study was carried out in Amansea and Ifite communities within the Awka Capital Territory. Awka is the Capital city of Anambra state, Nigeria and is situated about $72 \mathrm{~km}$ away from Enugu and $45 \mathrm{~km}$ from Onitsha, along Enugu-Onitsha highway. Awka is situated in the rainforest belt of Nigeria and has two clearly demarcated seasons: a wet season from April to October and a dry season from November to March. The people of Awka practice both intensive and extensive poultry management system. Amansea and Ifite are communities within the Awka Capital Territory, and are separated by a small marshy stream. This study was carried out from June to September, 2014.

\subsection{Examination of Chicken for Infestation by Ectoparasitic Arthropods}

A total of 112 chicken (G. domesticus), 56 from Amansea and Ifite respectively, were used for this study. The chickens were caught at night fromtheir sleeping/roosting sites on trees and cages. The chickens were examined for ectoparasitic arthropod infestation in the morning of the next day. A careful approach was followed to detect and collect the ectoparasites. A hand lens was used to examine the different parts of the chicken for ectoparasites. A white cloth was spread on the ground while examining the chicken and during examination of the fowls, the head of the chicken was examined first, followed by the neck, body sides (using a soft brush for combing of the feathers), vent area and legs as described by [13]. The sample consisted of 42 (forty-two) adult males, 30 (thirty) adult females and 40 (forty) juveniles.

\subsection{Collection and Preservation of Ectoparasites}

Ectoparasites such as ticks were removed with the aid of a forceps and cotton wool soaked with alcohol to paralyze the ticks, for easy extraction. Lice were collected from hosts by dipping a dissecting forceps in absolute alcohol before extracting the lice. The alcohol instantly paralyzed the lice and thus made collection easier. Mites andfleas were collected by brushing of the head and body of the fowl as described by [14] [15]. All the parasites collected were counted and placed in sampling bottles containing 70\% ethanol. Each fowl examined was assigned a serial number on the sampling bottle for ease of identification. All parasites collected were sent to Department of Zoology Laboratory in NnamdiAzikiwe University, Awka for thorough study and identification.

\subsection{Identification of Ectoparasites}

The ectoparasites were placed on a microscopic slide and viewed with the aid of a dissecting and binocular microscope to study their morphological characteristics for identification. The identity of the ectoparasites was established using identification guides by [16].

\subsection{Statistical Analysis}

Chi-squared test was used to test for possible significant differences between the parameters investigated, using SPSS statistical software package.

\section{Result and Discussion}

Table 1 shows that out of the 12 G. domesticushaving white plumage, $(58.33 \%)$ were infested with lice. Fleas were absent on white plumage birds. $19 \mathrm{G}$. domesticus having black plumage, $(47.37 \%)$ were infested by lice. Fleas were absent on black plumage birds. Reasons are unknown, which demands for more research to be conducted. Out of 34 brown coloured G. Domesticus examined, lice, fleas and mites were recorded to have the same number of infestation $(17.65 \%)$ each, while $(29.41 \%)$ of the $34 \mathrm{G}$. domesticus examined were infested by ticks. Out of 47 G. domesticus having mixed colour plumage, $(40.42 \%)$ were infested by lice. Chi-squared test showed that there was no significant difference between ectoparasites and the different plumage colours of the hosts $(\mathrm{P}>0.05)$. 
Table 1. Prevalence of ectoparasitic arthropods on free range domestic fowls (G. domesticus) with different colouredin Amansea and Ifite communities, in Awka

\begin{tabular}{|c|c|c|c|c|c|c|c|c|c|c|c|c|}
\hline & Lice & Fleas & Ticks & Mites & & Lice & Fleas & Ticks & Mites & & Lice & Fleas \\
\hline Colours & N.E & N.I & Prevalence(\%) & N.E & Colours & N.E & N.I & Prevalence(\%) & N.E & Colours & N.E & N.I \\
\hline White & 12 & 7 & 58.33 & 12 & White & 12 & 7 & 58.33 & 12 & White & 12 & 7 \\
\hline Black & 19 & 9 & 47.37 & 19 & Black & 19 & 9 & 47.37 & 19 & Black & 19 & 9 \\
\hline Brown & 34 & 6 & 17.65 & 34 & Brown & 34 & 6 & 17.65 & 34 & Brown & 34 & 6 \\
\hline Mixed & 47 & 19 & 40.42 & 47 & Mixed & 47 & 19 & 40.42 & 47 & Mixed & 47 & 19 \\
\hline
\end{tabular}

Keys $=$ N.E - number examined, N.I - number infested.

Table 2. Distribution of Ectoparasitic Arthropods on the body of Free Range Domestic Chicken (G. domesticus) in Amansea and Ifite Communities Awka

\begin{tabular}{|l|l|l|l|}
\hline Ectoparasitic Species & Order & Family & Location on G.domesticus \\
\hline Menopongallinae & Phthirapteras & Menoponidae & Entire body \\
\hline Lipeuruscaponis & Phthiraptera & Philopteridae & Head, feathers \\
\hline Goniocotesgallinae & Phthiraptera & Menoponidae & Feathers \\
\hline Echidnophagagallinacea & Siphonaptera & Pulicidae & Comb, wattle, eye, \\
\hline Dermanyssusgallinae & Mesostigimata & Dermanyssidae & Entire body \\
\hline Argaspersicus & Ixodida & Argasidae & Head, neck \\
\hline
\end{tabular}

Table 2 above shows that M. gallinae and. D. gallinae occurred on the entire body, L. caponis occurred on the head and feathers, $G$. gallinae on the feathers, $E$. gallinacean on the comb, wattle and eyes, A. persicus on the head and neck.

A total of six species of ectoparasitic arthropods were recorded in the $G$. domesticus population involved in the study. These included three species of lice namely, Argas persicus (Figure 1), Lipeurus caponis (Figure 2) and Menopon gallinae (Figure 3), One species of flea namely, Echidnophaga gallinacean (Figure4), one species of the mite namely, Dermanyssus gallinae (Figure5) and one species of soft tick namely, Goniocotes gallinae (Figure 6).

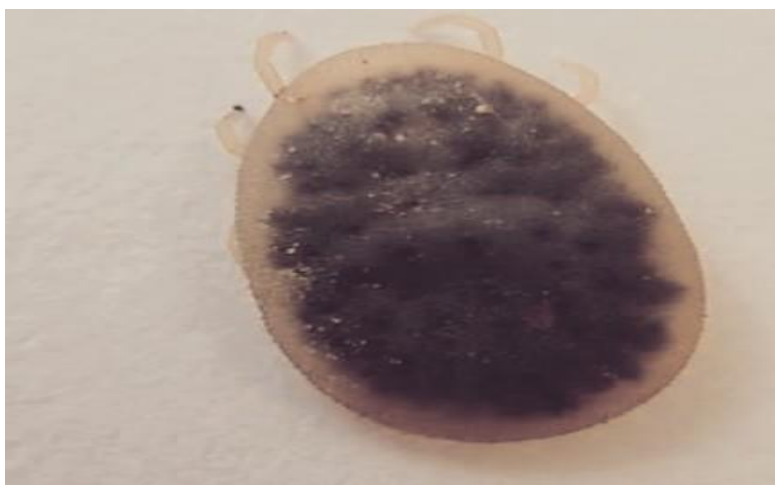

Figure 1. Argaspersicus isolated from G. domesticus from Amansea and Ifite communities

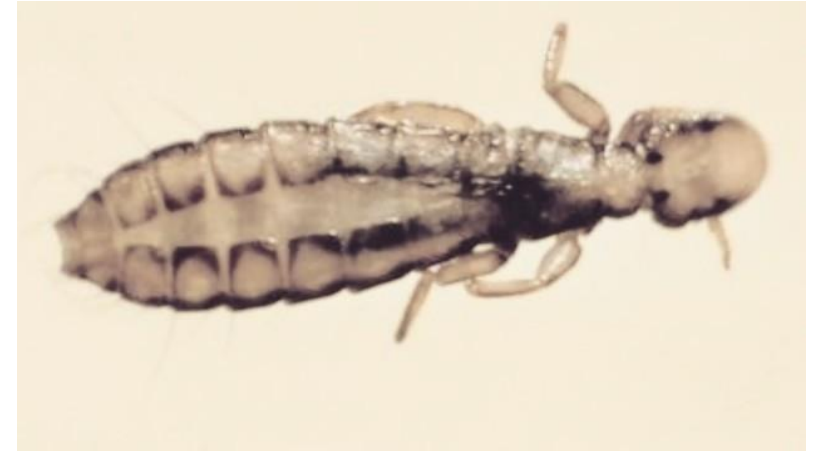

Figure 2. Lipeurus caponis isolated from G.domesticus in Amansea and Ifite communities

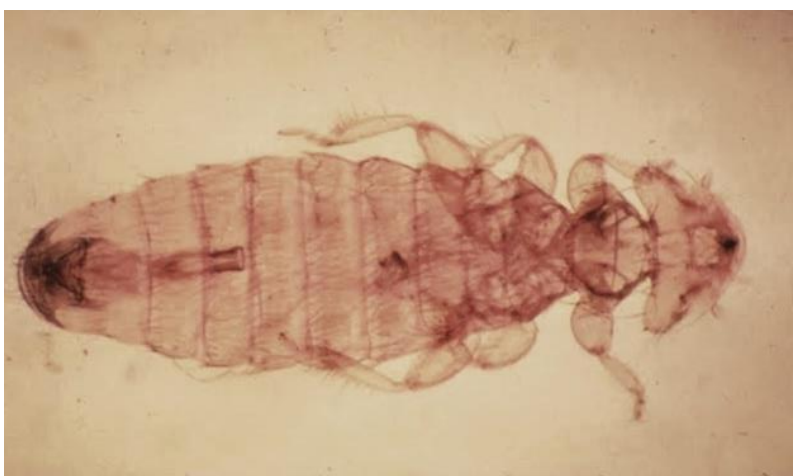

Figure 3. Menopon gallinae isolated from G. domesticus in Amansea and Ifite communities 


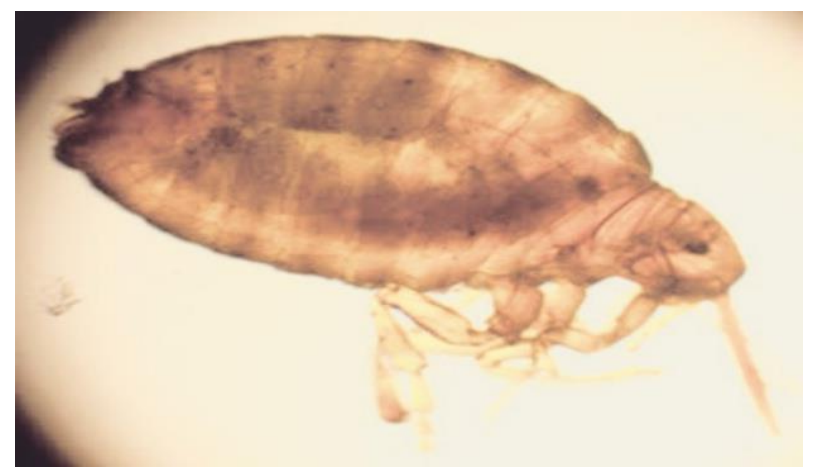

Figure 4. Echidnophaga gallinacean isolated from G.domesticus in Amansea and Ifite communities

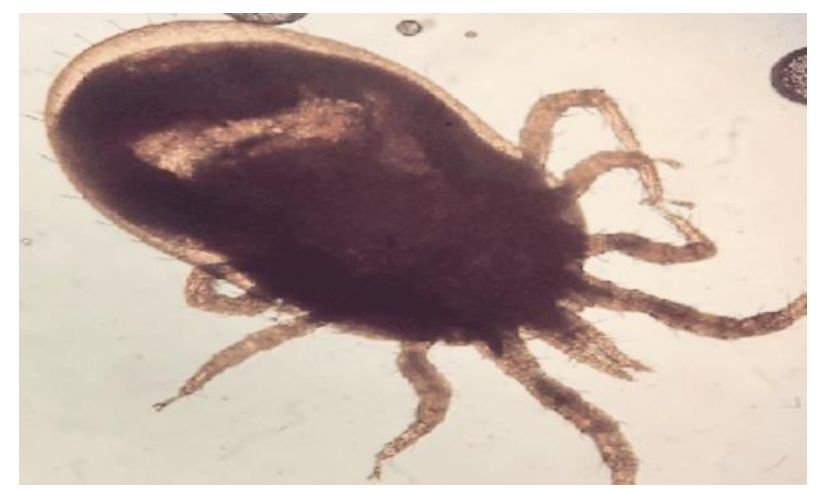

Figure 5. Dermanyssus gallinae isolated from G.domesticus in Amansea and Ifite communities

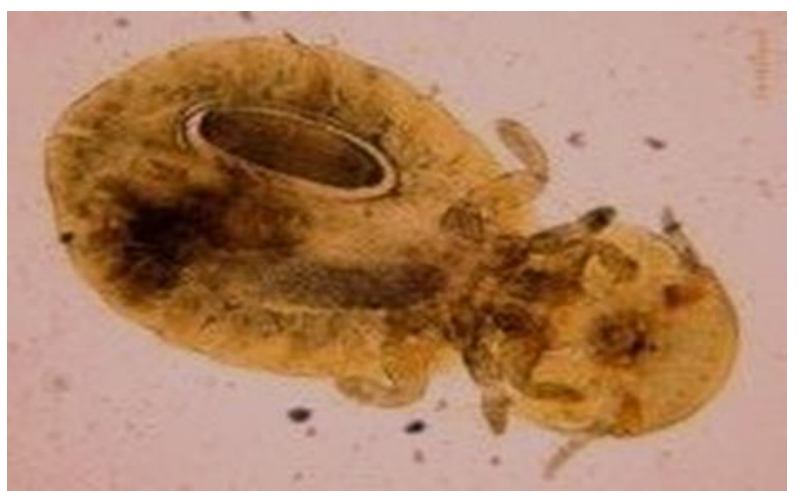

Figure 6. Goniocotes gallinae isolated from G.domesticus in Amansea and Ifite communities

According to the findings of this present study (Table 1), Lice 19 (40.42\%), Fleas 6 (12.77\%) and ticks 16 (34.04\%) were found to occur more on mixed coloured chicken, while Mite $10(52.63 \%)$ was found to occur more on black coloured birds. These findings agree with that of [14], who found that mixed coloured chicken were more infested with the ectoparasites (Lice, ticks and fleas) $(50.0 \%)$ as against $21 \%$ for white coloured and 29\% for blacked coloured chicken. In contrast, the findings of the present study differ from those of [17] who recorded that black colour feather chicken had the highest prevalence (66\%) than brown-red $(56 \%)$, white (49\%) and mixed coloured (12\%). Fleas were absent on white and black plumage birds. The reasons for this situation are unknown, which demands for moreresearch to be conducted. The findings of these studies suggest that plumage colour could be a factor that influences prevalence of ectoparasitic arthropods in $G$. domesticus.

According to the findings of the present study (Table 2), the different ectoparasites were found in different microhabitats on the body of the chicken. This finding agrees with that of [18], who found M. gallinae, L. caponis, and G. gallinae on the feathers and undersides of the large wings, while $D$. gallinae was found to be on the entire body of the fowl. [19] also reported finding E. gallinacean on the head of the affected chicken; the wattles, eyelids and combs, being heavily infested, as found in these present study. [20] reported finding D. gallinae moving rapidly throughout the body of the chicken; which corroborates the findings of the present study, where the mite was found on the entire body of the infested chicken.

Although the effects of the ectoparasitic arthropod species on the infested chicken was not evaluated in the present study, it could be significant, given the high prevalence, and the adverse effects which some of the species recorded in the present study are known to have on their hosts. A. persicus for instance, is known to harbor different types of bacteria and causes paralysis in chicken [6]. Echidnophagagalliancea could cause blindness in birds as they cluster around their eyes as was found in the present study. Further E. galinaceahas been reported to infest chicken, humans, turkey, cats and dogs [21]. This makes the species a potential agent of zoonosis. According to [4] arthropod ectoparasites have major impact on husbandry, productivity and welfare of domestic animals. [5] listed blood loss, myiasis, skin inflammation, pruritis and toxic and allergic responses as some of the direct damages, while disturbance, social nuisance and self-wounding are indirect damages which arthropod ectoparasites cause. [6] stated that severely affected birds may die. Thus, there is little doubt that the arthropod ectoparasites recorded in the present study could be causing varying degrees of damage/harm to the infested birds, and hence to poultry business in the two communities of Amansea and Ifite, in Awka Capital territory.

\section{Conclusions}

In conclusion, the present study has provided information on the various ectoparasitic arthropods of domestic chicken in Amansea and Ifite communities. Therefore, further study is needed to determine the impact of infestation on the health and productivity of these birds, and evaluation of cost benefit of various control strategies need to be investigated. Meanwhile, it would be opined that there is an important need to put a strategy for reducing or eliminating ectoparasitic arthropod parasites of chicken 
from the communities in place. Dusting the chicken and their roosting places with appropriate insecticides/acaricides would be an effective strategy.

\section{REFERENCES}

[1] Oluyemi JA, Adene DF, Ladoje GO.A comparison of indigenous fowl with rock under conditions of disease nutritional stress. Trop. Anim. Health Prod; 11:191-202, 1978.

[2] HormingGS, Rasmussen AS, Permin A and Isgaard MB. Investigation of the influence of helminthes parasites on vaccination of chickens against Newcastle disease virus under village conditions. Trop. Anim. Health Prod; 35:415-424, 2003.

[3] Adene DF and DipeoluOO. A survey of blood and ectoparasites of domestic fowls in Ibadan, Western state of Nigeria. Bulletin of Animal Health Production in Africa; 23:333-335, 1975.

[4] Colebroke E and Wall R. Ectoparasites of livestock in Europe and the Mediterranean region. Veterinary Parasitology; 120:251-274, 1991.

[5] Richards W and David S. Veterinary ectoparasites: Biology, pathology and control. 2nd edition. Blackwell science LTD, Oxford. 2011

[6] SoulsbyEJL. Helminthes, Arthropods and Protozoa of domesticated animals, 7th edition. BailliereTindall and Cassel LTD, London. 1982

[7] Permin A and Hansen J. the epidemiology, diagnosis and control of poultry parasites. FAO report, Rome, Italy. 1998

[8] ArendsJJ. External parasites and poultry pests. In diseases of poultry. 11th edition. Edited by Calnek WB, John H, Beard WC, McDougaldLR and SaifYM. Iowa state press, Blackwell publishing company, Ames, Iowa. 2003.

[9] Berriatua E, French NP, Broster CE, Morgan KL and Wall R.Effect of infestation with Psoroptesovis on the nocturnal rubbing and lying behaviour of housed sheep. Applied Animal Behaviour Science; 7: 143-155, 2001.

[10] Nithikathkul C, Polseela R, Iamsa-ard J, Wongsawad C and Jittapalapong S. A study of ectoparasites of Canis lupus familiaris in Mueang district, KhonKaen, Thailand. Southeast Asian Journal of Tropical Medicine and Public Health; 36(4):149-151, 2005.

[11] Shimada Y, Beppu T, Inokuma H, Okuda M and Onishi T. Ixodid tick species recovered from domestic dogs in Japan.Medical and Veterinary Entomology; 17: 38, 2003.

[12] TolossaYH, ShafiZD and Basu AK. Ectoparasites and gastrointestinal helminths of chickens of three agro-climatic zones in Oromia Region, Ethiopia Animal Biology; 59(3): 289-297, 2009

[13] Banda Z. Ectoparasites of indigenous Malawi chickens. Aust. J. Basic and Applied Sci.; 5(6):1454-1460, 2011.

[14] Bala AY, Anka SA, Waziri A and Shehu H. preliminary survey of ectoparasites infesting chickens (Gallus domesticus) in four areas of Sokoto metropolis. Nigerian Journal of Basic and Applied Science; 19(2):173-180, 2011.

[15] Mukaratirwa S and Khumalo MP. Prevalence of chewing lice in free-range chickens from selected rural localities of Kwazulu-Natal, South Africa. International Journal of Applied Research and Veterinary Medicine; 10(!):85-89, 2012.

[16] Wall R and Shearer D. Veterinary Entomology. 2nd edition, Blackwell sci. LTD, Oxford. 1997.

[17] Surman A, Sandeep N and Suneel KS. Prevalence of Menopongallinaelinn. (Insect, phthiraptera, menopon idea, amblycera) upon poultry birds (Gallus domesticus) of selected locality of district ChamoliGarhwal (Uttarakhand), India. Journal of Applied and Natural Science; 5(2):400-405, 2013.

[18] SabuniZA, Mbuthia PG, Maingi N, NyagaPN, NjagiLW, Bebora LC and Michieka JN. Prevalence of ectoparasite infestation in indigenous free-living village chicken in different agro ecological zones in Kenya. Livestock Rural Research and Development (LRRD). 2010.

[19] IkpezeOO, Amagba IC and Eneanya CI. Preliminary survey of ectoparasites of chicken in Awka, Southeastern Nigeria. Animal Res. Intern; 5(2):848-851, 2008.

[20] Shanta IS, Begum N, Anisuzzaman AS, Bari M and Karim MJ. Prevalence and clinic-pathological effects of ectoparasites in backyard poultry. Bangladesh J. Vet. Med.; 4(1):19-26, 2006.

[21] Tanasak C, Ruangrat B, Sarin S, Jarunee S, Plern Y, Kecha C, Juthiathip J, Charoonluk S and Parntep R. A survey of ectoparasitic arthropods on domestic animals in Tak province, Thailand. Soutwest Asian of Tropical Medicine and Public Health; 40(3):453-442, 2009. 